\title{
Theoretical Bases and Methodological Conditions for Organizing Public Procurement
}

\author{
Tulkin Atamurodov Tuymurodovich
}

\begin{abstract}
The article discusses the types of public procurement and their differences. In this regard, the findings of scientists in their scientific works are studied and the author's authoritative approach is described. As a result of the research, scientific recommendations and recommendations were developed.

Index Terms-Government procurement, online store, auction, selection, tender, direct government procurement, individual suppliers
\end{abstract}

\section{INTRODUCTION}

Formation and constant improvement of the legal basis for organizing public procurement in any country is one of the important strategic objectives of public finance management. Therefore, process of organizing public procurement begins with defining its organizational forms. Based on the norms established by international and national legislation, the form of procurement shall be determined and the necessary regulatory procedures will be administered by the customer.

In general, it is possible to create conditions for macroeconomic stability through effective public procurement. In particular, it is important to develop mechanisms for assessing public procurement and thereby setting the direction for improving its efficiency. In this regard, Kryukova's (2012) study is of particular importance. According to her, the effectiveness of procurement can be assessed through several indicators:

- Effective budget planning;

- Share of unsigned contracts on public procurement processes;

- Timely delivery of goods (works, services);

- Effective use of budget funds;

- Execution of contract for delivery;

- Execution of contract on the quality of goods;

- Percentage of contracts terminated during execution of signed contracts.

It should be noted that the evaluation of budget expenditures in public procurement has a specific character. For example, it is difficult to compare the processes of grocery shopping with the construction industry. In our opinion, it is important to consider the factors that determine the effectiveness of budget spending when choosing public procurement models.

This research analyzes the types of public procurement and their emerging conditions and forms an independent author's approach to them.

\section{LITERATURE REVIEW}

In public procurement models, contractual relations are seen as fundamental issues. For example, in the US, where centralized public procurement is concerned, it involves creating anti-corruption, fairness in determining the winners, and cost-effectiveness and efficiency. In the US, centralized public procurement is administered by the General services administration. Such large centralization will help to reduce budget costs by achieving large volumes of goods (works, services).

The state can also support national producers by providing certain benefits in the process. Procurements are also made on the basis of standardized standard contracts.

The European model is also decentralized. According to a study by Adler (2007), the organization of public procurement involves the purchase of innovative products aimed at high-tech development. According to him, it is one of the key areas in the development of innovative policies in the EU countries.

Not all EU states are decentralized. Nevertheless, their basic basis is related to the elements of contracting process organization. In general, the main principles of the contract are: transparency, fairness, accountability and competition.

M. Falagario (2012) studied the algorithm of public procurement model in the EU.

According to European rules, the contracting service should pre-determine the criteria for evaluating bids in accordance with the "Relatively Profitable" rules.

According to the method developed by the author, all proposals are transparently evaluated by the public service using the same methodology.

It is also important to note that the most important aspect of procurement in EU countries is the advantage given to national manufacturers / suppliers. G. Walker and according to a survey conducted by S. Brammer (2009) in the UK, the analysis of quantitative and qualitative indicators shows that there are mutually exclusive characteristics. In particular, if local authorities give preference to local producers, education and health care institutions are procuring goods in connection with environmental issues. 
TABLE 1. INDICATORS CHARACTERIZING THE EFFECTIVENESS OF PUBLIC PROCUREMENT IN THE CONSTRUCTION SECTOR

\begin{tabular}{|c|c|c|}
\hline Main indicator & \multicolumn{2}{|c|}{ Object of evaluation of secondary indicator } \\
\hline \multirow{3}{*}{$\begin{array}{l}\text { Efficiency of } \\
\text { budget } \\
\text { allocation }\end{array}$} & \multicolumn{2}{|c|}{ General procurement assessment } \\
\hline & \multirow[t]{2}{*}{ Assessment by stages } & Contract sales \\
\hline & & Execution of the contract \\
\hline \multirow{3}{*}{$\begin{array}{l}\text { Monitoring of } \\
\text { procurement } \\
\text { terms }\end{array}$} & \multicolumn{2}{|c|}{ General procurement assessment } \\
\hline & \multirow[t]{2}{*}{ Assessment by stages } & Contract sales \\
\hline & & Execution of the contract \\
\hline \multirow{3}{*}{$\begin{array}{l}\text { Quality of } \\
\text { purchase (on } \\
\text { completed } \\
\text { contract) }\end{array}$} & \multicolumn{2}{|c|}{ Project object conformity to design and requirements } \\
\hline & \multicolumn{2}{|c|}{ Completeness of work done } \\
\hline & \multicolumn{2}{|c|}{ Correction of defects and errors } \\
\hline \multirow{3}{*}{$\begin{array}{l}\text { Effective } \\
\text { procurement } \\
\text { management }\end{array}$} & \multicolumn{2}{|c|}{ General procurement assessment } \\
\hline & \multirow[t]{2}{*}{ Assessment by stages } & Contract sales \\
\hline & & $\begin{array}{l}\text { Construction } \\
\text { management }\end{array}$ \\
\hline
\end{tabular}

In our opinion, the complete and decentralized implementation of existing public procurement models may not be fully effective. Therefore, it is advisable to select a particular model of goods (works, services) based on the state budget and extra-budgetary funds. For example, in the implementation of health services, it is important to carry out decentralized care in the construction area, if certain types of drugs are centralized.

Russian scientist M.Demidenko (2017) shows the use of a centralized model for public procurement in the construction industry and its performance evaluation. In particular, it distinguishes the quality and timing parameters (see Table 1).

In his research, M.Demidenko points out that the high efficiency of public budget spending is more than $10 \%$ in public procurement. Budget savings in contract sales mean ineffectiveness, and this figure indicates that this figure represents regulatory effectiveness.

It is also due to the fact that it is possible to strengthen the competitive environment through public procurement. It allows one to effectively use budgetary expenditures and, on the other hand, promotes competition among economic entities. In this regard, N. Zaikin (2015) notes that public procurement is an integral part of improving the competitive environment management mechanism.

At the same time, the organization and management of public procurement includes four interconnected elements. These elements are complex in nature and are a factor in the successful implementation of each element and the efficiency of public procurement. Specifically, they are:

- Planning of public procurement;

- Organizational forms of procurement;

- Concluding and executing contracts;

- Public procurement control system.

Public procurement planning is carried out in the process of budgeting for the next period and the formation of a nomenclature of public needs financed by partial full public funds. This process includes:

formulating and submitting to the financial authorities financial inquiries for budgeting of goods (works, services) for state needs;

approval of the budget for public procurement budgeting on the basis of inquiries and informing recipients of budget allocations;

registration of expenditure estimates for the goods and services purchased.

Nowadays, when studying the practice of public procurement planning in Uzbekistan, although the law provides for a 'bottom-up' mechanism for the flow of information about the demand of government agencies and organizations for goods (works, services), the funding for these needs is unilaterally "top-down. ". This is done by removing (reducing) the "non-essential", "redundant" and "unjustified" cost sections from the list of needs of government agencies and organizations. Based on this type of planning mechanism, a normative-cost method is used to determine the needs of budget administrators and the amount of funding available to them.

It is noted that customers should consider the following financial and technological factors when planning public procurement (Anchishkina, 2011):

-Price targets;

-Necessary expenses;

-Mandatory expenses;

-Costs associated with price fluctuations and their quality; costs associated with the life of the product.

I. Smotritskaya (2011) emphasizes the importance of planning the types and types of goods (works, services) in organizing public procurement as part of contractual relations.

-Optimizing infrastructure development investment programs by reducing the cost of facilities and services;

-Financial transparency of budget expenditures;

-Reduction of project implementation deadlines;

Increasing supplier liability and quality assurance by introducing payment for object quality.

In our view, it would be expedient to take into account the necessary volume of goods (works, services), as well as the factors that contribute to the planning of the above. Therefore, the main criterion in budgeting is the establishment of high expenditure limits, taking into account specific demand for goods (works, services).

In other words, the goal is to ensure that the funds allocated are sufficient to meet real needs. Therefore, the surplus that emerges at the end of the fiscal year does not mean that the financial needs of public authorities are fully met and that these resources are excessive.

However, C. Ambaryan (2015) examines some of the problems in procurement planning. The budget customer can plan expenses without having a clear idea of the market price of the product (work, service) for his / her needs.

Therefore, the author recommends the introduction of a functional conceptual model of an automated information system to address such problems.

In our view, the reasons for existing problems in public procurement planning are:

-imperfection of the budget process - budget formulation is only within one year, with no obligation to finance projects 
envisaged or completed in the previous year's budget;

- cost of public procurement of one calendar year of the period preceding the procurement period will be compounded by the price constraints.

Insufficient improvement of the methodological framework for the formation of the state budget, ie low level of mutual independence in the planning of revenue and expenditure items.

Based on the research, we believe it is advisable to introduce an electronic program of data that reflects the mechanism for determining the future market value of goods (works, services) needed in budget planning.

As we continue our research, we will focus on the organizational types of public procurement.

In particular, Y.Kryukova (2012) summarizes the important aspects of public procurement system development at the regional and national levels. In particular, they approach the public procurement from a regional perspective and propose ways to achieve efficiency as a result of a combination of public procurement and spending planning. The general structure of his conclusions can be clearly seen in Figure 1 below:

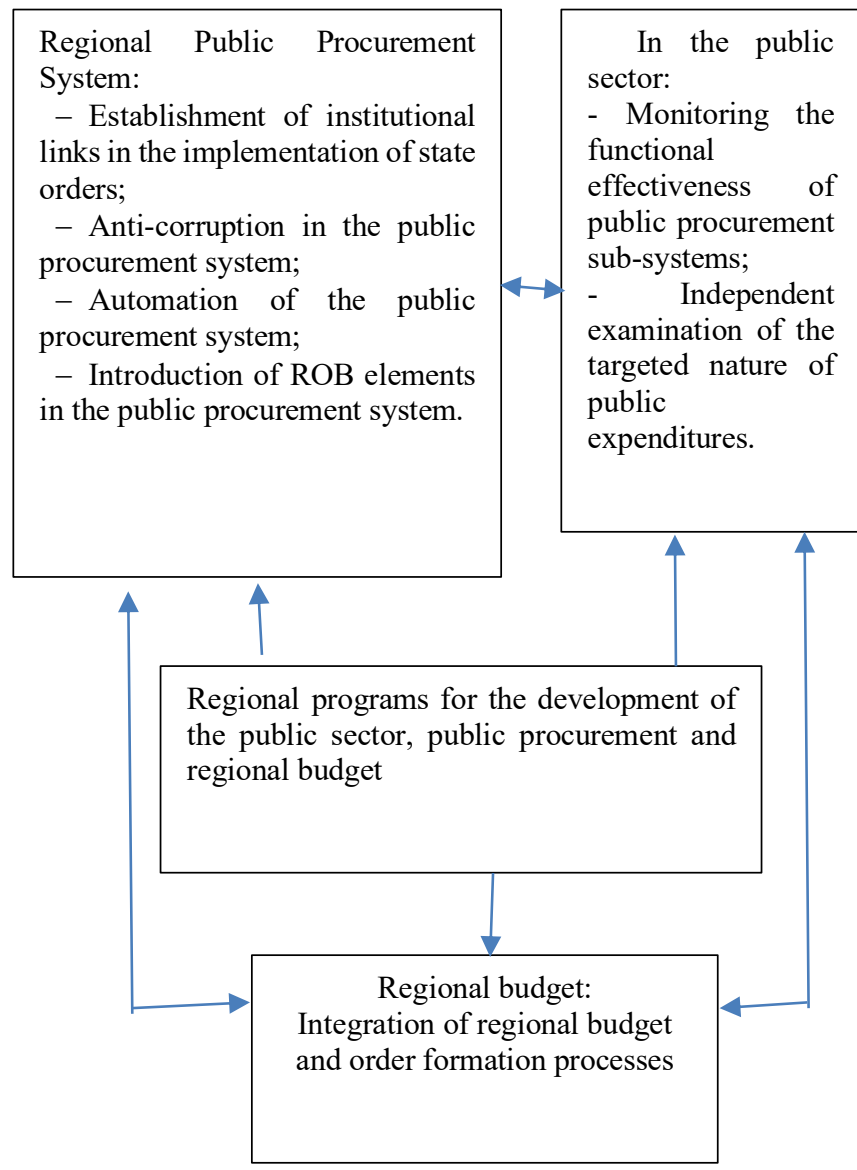

Fig. 1 Public procurement system development

M. Sedova (2015) conducted research on public procurement financing. It also draws conclusions on the forms and features of public procurement based on competition. They note that public procurement forms occur through contracts and through direct (non-tradable) contracts (see Figure 2).
TABLE 2.FORMS AND ORGANIZATIONAL ASPECTS OF PUBLIC PROCUREMENT

\begin{tabular}{|c|c|c|c|}
\hline $\begin{array}{l}\text { Form of } \\
\text { purchase }\end{array}$ & $\begin{array}{l}\text { Subject of } \\
\text { trade }\end{array}$ & Budget customer & $\begin{array}{l}\text { Corporate } \\
\text { customer }\end{array}$ \\
\hline \multirow{3}{*}{$\begin{array}{l}\text { Electronic } \\
\text { store }\end{array}$} & \multirow[t]{2}{*}{ Merchandise } & $\begin{array}{l}\text { MI (minimum } \\
\text { income) up to } 25 \\
\text { times }\end{array}$ & $\begin{array}{l}\text { MI up to } 250 \\
\text { times }\end{array}$ \\
\hline & & \multicolumn{2}{|c|}{ MI up to 2,500 times a year } \\
\hline & $\begin{array}{c}\text { Work, } \\
\text { service }\end{array}$ & \multicolumn{2}{|c|}{ MI up to 250 times } \\
\hline Auction & Merchandise & $\begin{array}{c}\text { MI up to } 2500 \\
\text { times }\end{array}$ & $\begin{array}{c}\text { MI up to } 5000 \\
\text { times }\end{array}$ \\
\hline \multirow{2}{*}{ Competition } & Merchandise & $\begin{array}{l}\text { MI is in range of } \\
2500-6000 \text { times }\end{array}$ & $\begin{array}{l}\text { MI is in range } \\
\text { of } 5000-25000 \\
\text { times }\end{array}$ \\
\hline & $\begin{array}{l}\text { Work, } \\
\text { service }\end{array}$ & $\begin{array}{l}\text { MI is in range of } \\
25-6000 \text { times }\end{array}$ & $\begin{array}{l}\text { MI is in range } \\
\text { of } 25-25000 \\
\text { times }\end{array}$ \\
\hline Tender & $\begin{array}{l}\text { Merchandise, } \\
\text { work, service }\end{array}$ & MI is above 6000 & $\begin{array}{c}\text { MI is above } \\
25000\end{array}$ \\
\hline $\begin{array}{l}\text { Single } \\
\text { supplier }\end{array}$ & $\begin{array}{l}\text { Merchandise, } \\
\text { work, service }\end{array}$ & \multicolumn{2}{|c|}{$\begin{array}{c}\text { cultural values, goods (works, services) } \\
\text { of the subject of natural monopoly, } \\
\text { having no alternative in the market }\end{array}$} \\
\hline $\begin{array}{l}\text { By direct } \\
\text { contracts }\end{array}$ & $\begin{array}{l}\text { Merchandise, } \\
\text { work, service }\end{array}$ & \multicolumn{2}{|c|}{$\begin{array}{l}\text { According to the list approved by } \\
\text { Decree of the President of the Republic } \\
\text { of Uzbekistan dated September } 27 \text {, } \\
2018 \text { No. PP-3953 }\end{array}$} \\
\hline
\end{tabular}

Source. Compiled by the researcher on the basis of legal documents.

The adoption of the Law of the Republic of Uzbekistan № 472 of April 9, 2018 "On Public Procurement" clarified this issue. According to Article 23 of this Law, the following shall be the types of procurement procedures:

-e-shop;

-auction to reduce the starting price;

-choice;

-tender;

- public procurement carried out by a single supplier.

Also, by decree of the President of the Republic of Uzbekistan dated September 27, 2018 N PP-3953 “On Measures to Implement the Law of the Republic of Uzbekistan" On public procurement "goods (works, services) procured under direct contracts by state customers. The list is set.

The abovementioned public procurement forms are implemented electronically. It distinguishes between corporate and budget customers as state customers. For example, institutions that carry out their activities from budget funds participate in public procurement as budget customers. At the same time, state-owned enterprises that do not receive budget funds, legal entities with a state share in the authorized capital (authorized capital) of 50\% and more, and also legal entities with $50 \%$ or more of the authorized capital (charter capital). Legal entities owned by a person may operate as a corporate customer (see Table 2). 


\section{RESEARCH METHODOLOGY}

The study provides a systematic analysis of scientific works aimed at identifying the types of public procurement. Also, information analysis is carried out on the basis of electronic public procurement site - special information portal.

\section{ANALYSIS AND RESULTS}

Electronic public procurement is carried out on a special information portal. This portal is operated by an operator authorized by the competent authority. Regulation of the national project management agency under the President of the Republic of Uzbekistan dated May 15, 2018 No 186 "On approval of the activities of the Special information portal operator on Public procurement and conducting" ) the Operator must meet the following requirements:

- Availability of an electronic information system that ensures the placement and use of public procurement information, guarantees of fulfillment of obligations through the ICMP, processing of statistical information on public procurement;

- $\quad$ Availability of skilled e-commerce and information technology personnel;

- Placement of the portal on hardware and software on the territory of the Republic of Uzbekistan;

- $\quad$ Failure to apply bankruptcy procedures against him.

The special information portal automatically deducts its commission from the advance payment in the clearing house (apch) after the contract is concluded.

Goods (works, services) are placed in the electronic store in the form of a public offer by the supplier for 15 days. During this time, the supplier may make changes to the offer. The customer offers the best price for the goods (works, services) within his / her own needs and expenses. After sending the price request by the Customer, the supplier shall submit the request to the customer within 48 hours. This will result in the purchase of e-commerce and completion of public procurement. Then the contract is automatically signed by the portal.

Unlike an e-store at the auction, the price offer is made by the supplier. At the same time, a trade agreement is concluded with the subject who offered to enter into the lowest contract.

The auction is carried out by step-by-step reduction of the starting price in the electronic system. The step size is determined by the operator in consultation with the competent authority, but may not exceed the amount of advance payment by the participant.

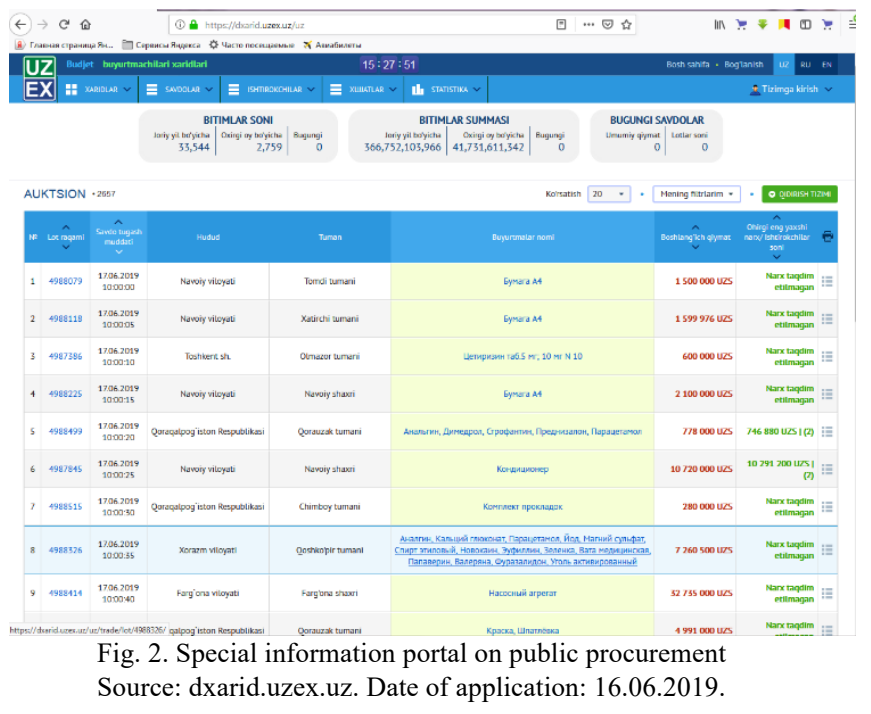

The auction will be held simultaneously with the following conditions:

- $\quad$ Standard characteristics of the goods;

- $\quad$ There is no need to evaluate and compare technical, operational and other characteristics of the goods;

- No object of public procurement of works and services.

Below we briefly consider the process of creating ecommerce. It should be noted that advance payments are returned to the corporate customer and supplier in the event of contractual obligations or new offer winning. We can say that e-purchases are only available at e-shops and auctions. Electronic purchases are made through a special information portal. This portal is available at https://dxarid.uzex.uz/uz, where participants can purchase EDS for public procurement. The initial version of this site will display the same lot number (by use, technical and functional specifications), expiration date, customer's location, area, name of the order, initial price and best bid information in real time (Figure 3 ). See also.

It should be noted that all information of the customer is clearly visible at the beginning of trading on this information portal. However, the information of the bidder (supplier) is not allowed.

Based on the research, it can be said that the auction announcements for the special information portal show that the prices for each lot differ significantly from the market price, or that the requirements for volume (size) of goods differ from the general standards. For example, the technical data on WS (Wooden slab) was $2.75 \times 1.7 \mathrm{~m} 2$ with a standard surface of 3 and $4 \mathrm{~mm}$ thick and weighed 12 and $16 \mathrm{~kg}$, respectively. 


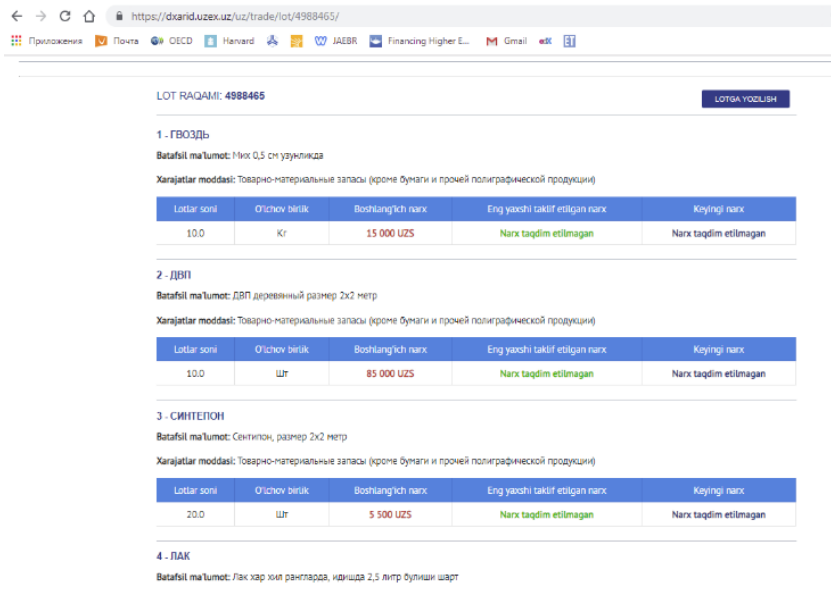

Figure 3 Source: dxarid.uzex.uz. Date of application: 16.06.2019.

As an example, our WS (Wooden slab) product weighs in the size of $2 \times 2 \mathrm{~m} 2$ shown in Figure 3. The requirements for its thickness and technical specifications for its weight are not given. Also, in the first lot as shown in Figure 3, the "A4" is advertised for a unit (500 sheets) of goods. During our inquiry into this special information portal, it was found that the price of one unit (500 pages) of "Sheet of paper A4" (Svetocopy) at 27,000 sums was studied on the website www.olx.uz.

\section{CONCLUSIONS}

In our opinion, when placing public procurement announcements on a special information portal, we think it is advisable to consider the following factors:

- Establishment of lots by the manufacturer (supplier) of the goods (works, services) on the basis of the technical passport of the trade subject, or the mechanism of declaring the goods (works, services) by the state standards in the formation of lots;

- Creation of real-time software for automated comparison and detection of market prices when setting prices for trade items.

We believe that it is advisable to reduce the amount of competitive bidding by increasing the maximum amount set for auction.

In our opinion, the introduction of the aforementioned cases should not be allowed, first of all, for procurement of the same type of goods by the budget customer under two (or more) costs estimates. Secondly, it is not possible to manipulate prices by the budget customer, and thirdly, efficiency is achieved by ensuring that budget spending is targeted.

The public procurement through a competitive tender shall be subject to the following conditions:

- It is possible to describe a detailed and accurate description of the product (work, service);

- Criteria for determining the winner will be not only the expression of money but also the quantity and quality of public procurement of goods (works, services).

In our view, the tendency to establish unsuccessful auctions for public procurement of bidding will be conducive to the aforementioned circumstances of the auction. Therefore, we believe it is expedient to abolish the bidding process of unsuccessful bidding and to reduce the procedures for the direct implementation of the bidding on the basis of minutes of the Cabinet of Ministers of the Republic of Uzbekistan.

It should be noted that there is a sharp difference between the tender and the tender in the sums set for holding them, and is characterized by two stages of tendering. The bidding will be conducted in two stages, while the technical requirements are initially considered, and in the second round, competition between the winners of the first round will be held.

In our view, it is advisable to expand the scope of the auction by increasing their minimum bid price by integrating them into tendering and tendering. Therefore, we believe that the merging of bids and tenders will have practical effects.

Consequently, conditions for the organization of public procurement occur with the creation of a competitive environment and the conclusion of direct contracts.

\section{REFERENCES}

[1] J.Edler, I.Georghiou Public procurement and innovation Resurrecting the demand side, Research Policy, vol. 36, pp. 949-963. 2007.

[2] M.Falagario, F.Sciancalepore, N.Costantino, R.Pietroforte Using a DEAcross efficiency approach in public procurement tenders, European Journal of Operational Research, vol. 218, pp. 523-529. Issue 2, 2012.

[3] H.Walker, S.Brammer Sustainable procurement in the United Kingdom public sector, Supply Chain Management, vol.14, pp. 128137. Issue 2, 2009.

[4] C.Ambaryan Development of a public procurement management support system using conceptual modeling, XXI century: results of the past and problems of the present plus, vol. 6(28). Pp. 281-286. 2015.

[5] O.Anchishkina Public Procurement Planning: US Experience for developing contractual relations in the Russian Government, Federal Contract System. - M.: 2011. pp. 66-92.

[6] M.Demidenko. Development of contract tenders for the construction of facilities in the public procurement system: abstract ... Ph.D - St. Petersburg, p.23 . 2017.

[7] N.Zaikin. Features of the development of the competitive environment of Russia in the conditions of global instability: Ph.D. dissertation abstract, Ranepa under the President of the Russian Federation. Tomsk, 2015.

[8] Y.Kryukova Public procurement in the functioning and development of the regional economic system, Ph.D. dissertation abstract, Southern Institute of Management, Micon, 2012.

[9] M.Sedova Development of a mechanism for financing public procurement in Russia: Ph.D. dissertation abstract, Russian Academy of Entrepreneurship, Moscow, 2015.

[10] I.Smotritskaya The state as a subject of contractual relations in the context of the formation of an innovative economy, Federal contract system. Pp. 58-66. 2011.

[11] https://olx.uz/list/q\%D0\%B1\%D1\%83\%D0\%BC $\%$ D0\%B0\%D0\%B 3\%D0\%B0-\%D0\%904-Svetocopy/ 